\title{
Kontradiktif Sanksi Pidana Dalam Hukum Pajak
}

\author{
Wirawan B. Ilyas \\ Fakultas Hukum Universitas Al Azhar Indonesia \\ Jl. Sisingamangaraja, Kebayoran Baru Jakarta Selatan 12110 \\ kap_wbi@cbn.net.id
}

\begin{abstract}
This study is focused on the aspect of law enforcement, especially on tax law. The study additionally examines the process of tax laws enforcement that tends to emphasize on the criminal law rather than on administrative one. This research was conducted by using a normative juridical method focused on primary and secondary materials. The result of the research shows that merely emphasizing the criminal aspects of tax law enforcement will only jeopardizes the primary goal of tax administration in collecting tax revenue that is highly needed for public needs such as building schools, bridges, hospitals, fuel subsidies, and so on. Conversely, using an administrative approach will maximize tax revenue because it will make taxpayers and tax officers feel safe every time they face a tax dispute.
\end{abstract}

Key words : Administrative law, criminal law, government spending.

\begin{abstract}
Abstrak
Penelitian ini difokuskan pada aspek penegakan hukum, terutama di bidang hukum pajak. Selain itu juga penelitian mengkaji proses penegakan hukum pajak yang cenderung menekankan pada hukum pidana bukan pada hukum administrasi. Penelitian ini dilakukan dengan menggunakan metode yuridis normatif yang mendasarkan pada bahan hukum primer. Hasil penelitian menunjukkan bahwa, menekankan aspek pidana dalam penegakan hukum pajak hanya akan membahayakan tujuan utama administrasi pajak dalam mengumpulkan penerimaan pajak yang sangat dibutuhkan untuk belanja publik seperti membangun sekolah, jembatan, rumah sakit, subsidi bahan bakar, dan sebagainya. Di sisi lain, menggunakan pendekatan administratif akan memaksimalkan penerimaan pajak karena akan membuat pembayar pajak dan petugas pajak merasa aman setiap kali mereka menghadapi sengketa pajak.
\end{abstract}

Kata kunci : Hukum administrasi, hukum pidana, belanja pemerintah. 


\section{Pendahuluan}

Ketika sanksi pidana pajak mulai diterapkan kepada Wajib Pajak, tampaknya penerapan sanksi tersebut menimbulkan keresahan di kalangan pelaku bisnis. Persoalan pajak (hukum pajak) sebagai bagian dari hukum administrasi negara, sejatinya diselesaikan melalui cara-cara hukum administrasi, bukan hukum pidana. Pendekatan dengan cara pidana, pastinya akan menimbulkan keresahan serius. Namun, keresahan menjadi sedikit terhibur ketika 3 (tiga) orang saksi ahli memberikan pendapatnya dalam sidang lanjutan dugaan penggelapan pajak oleh PT. Asian Agri Group senilai Rp. 1.259.000.000.000,00 di Pengadilan Negeri Jakarta Pusat. ${ }^{1}$

Ketiga saksi ahli adalah M. Yahya Harahap (ahli Pidana). Philipus M. Hadjon (Ahli Tata Negara dan Administrasi Negara) dan Sunarto (ahli Pajak). Yahya Harahap, yang mantan Hakim Agung Mahkamah Agung, berpendapat konsep dan asas yang diterapkan dalam hukum pajak Indonesia bahwa kesalahan atau kekeliruan mengisi Surat Pemberitahuan (SPT) yang diatur dalam Pasal 8 jo Pasal 12 UU No. 6 Tahun 1983 sebagaimana telah diubah dengan UU No. 28 Tahun 2007 tentang Ketentuan Umum dan Tata Cara Perpajakan - UU KUP sebaiknya diselesaikan secara administrasi yang bermuara ke Pengadilan Pajak.

Begitupun Philipus yang menekankan bahwa tindakan mengimplikasikan sanksi pidana bersifat ultimum remedium. Tujuan pajak bukan untuk menghukum dan memberi nestapa kepada pelaku, tetapi mengakhiri pelanggaran dan memulihkan keadaan. Sedangkan Sunarto sebagai ahli pajak, lebih menekankan pada kewenangan Direktur Jenderal Pajak yang bisa menerbitkan Surat Ketetapan Pajak Kurang Bayar Tambahan berkali-kali. Penerbitan bisa dilakukan sebagai upaya penegakan hukum pajak sesuai Undang-undang pajak.

Pendapat ketiga ahli tersebut tampaknya senada dengan suara yang disampaikan kalangan pelaku bisnis. Ketua Umum Asosiasi Pengusaha Indonesia (Apindo), Sofyan Wanandi, menyatakan kasus Asian Agri tidak perlu dibawa ke ranah pengadilan pidana umum jika hakim mengerti masalah perpajakan. Wajib Pajak bisa dibawa ke pengadilan pidana jika memang melakukan pelanggaran hukum berupa tindak pidana. Namun, terkait masalah pajak, tidak perlu ditempuh jalur pidana. $^{2}$

\footnotetext{
${ }^{1}$ Harian Seputar Indonesia, "Sengketa Pajak Bukan Ranah Pengadilan Umum”, 23 Maret 2011; Harian Suara Pembaruan, "Negara Rugi Pidanakan Kasus Pajak”, 23 Maret 2011.

${ }^{2}$ Harian Suara Karya, "Penanganan Kasus Pajak Ancam Iklim Usaha", 25 Maret 2011.
} 
Pendapat ketiga ahli, baik ahli hukum maupun ahli pajak, yang dihadirkan ternyata kecenderungannya lebih memilih pada proses hukum administrasi ketimbang proses hukum pidana. Kecenderungan yang disampaikan para ahli bisa dipahami karena memang hukum pajak merupakan hukum administrasi yang memiliki jalur hukum administrasi apabila terdapat sengketa antara Wajib Pajak dengan petugas pajak (fiskus). Bahkan, dari sisi lain yaitu sisi penerimaan negara, dalam sepuluh tahun terakhir sangat jelas terlihat penerimaan pajak amat mendominasi sumber penerimaan negara yang ditampung dalam Anggaran Pendapatan dan Belanja Negara (APBN) dibandingkan sumber penerimaan negara dari sumber migas (minyak dan gas bumi).

Dalam kurun waktu sepuluh tahun terakhir, kenaikan penerimaan pajak tidak kurang dari Rp. 40.000.000.000.000,00 sampai Rp. 100.000.000.000.000,00 setiap tahunnya. Sebagai contoh, dalam kurun waktu enam tahun terakhir, terlihat angka penerimaan pajak sebagai berikut, 2005 diperoleh angka penerimaan sebesar Rp. 264.920.000.000.000,00, 2006 sebesar Rp. 333.010.000.000.000,00, 2007 sebesar Rp. 395.240.000.000.000,00, 2008 sebesar Rp. 483.890.000.000.000,00, 2009 sebesar Rp. 591.120.000.000.000,00, dan 2010 diperoleh angka penerimaan pajak sebesar Rp.649.040.000.000.000,00. ${ }^{3}$

Dengan kenaikan sumber penerimaan pajak yang setiap tahun terus meningkat, tentu diperlukan berbagai macam kebijakan yang dipandang perlu untuk merealisasikan penerimaan pajak tersebut. Terkait dengan itu, salah satu proses penegakan hukum di bidang perpajakan juga menjadi perhatian serius yang perlu dikaji, agar tujuan penerimaan pajak tidak terkendala dalam pelaksanaannya. Proses penegakan hukum pajak patut dipahami semua pihak termasuk para penegak hukum agar tidak menjadi kontraproduktif khususnya dalam menunjang penerimaan pajak untuk kepentingan negara dan kepentingan masyarakat.

\section{Rumusan Masalah}

Berdasarkan uraian di atas, permasalahan yang menarik untuk dikaji adalah pertama, mengapa penegak hukum (Kepolisian, Kejaksaan dan Pengadilan) lebih memilih pada pilihan hukum memidana Wajib Pajak. Kedua, dapatkah penegak

\footnotetext{
${ }^{3}$ Data diperoleh dari Direktorat Jenderal Pajak Tahun 2005 sampai dengan 2010.
} 
hukum memilih jalur hukum adminsitrasi dalam menyelesaikan sengketa pajak yang timbul antara Wajib Pajak dengan petugas pajak?

\section{Tujuan Penelitian}

Penelitian ini bertujuan pertama, mengetahui mengapa penegak hukum (Kepolisian, Kejaksaan dan Pengadilan) lebih memilih pada pilihan hukum memidana Wajib Pajak. Kedua, dapatkah penegak hukum memilih jalur hukum adminsitrasi dalam menyelesaikan sengketa pajak yang timbul antara wajib pajak dengan petugas pajak?

\section{Metode Penelitian}

Penelitian ini menggunakan pendekatan yuridis normatif dengan menggunakan bahan hukum primer ${ }^{4}$ terutama mengenai perundang-undangan di bidang perpajakan, khususnya Undang-Undang Nomor 6 Tahun 1983 tentang Ketentuan Umum dan Tata Cara Perpajakan sebagaimana telah diubah dengan Undang-Undang Nomor 16 Tahun 2009. Selain itu juga digunakan bahan hukum sekunder yang memberikan penjelasan mengenai bahan hukum primer, yaitu berupa buku-buku perpajakan serta berbagai informasi lain yang diperoleh dari artikel, press release, media massa. Pendekatan penelitian dilakukan dengan menggunakan pendekatan undang-undang dan pendekatan kasus di bidang perpajakan.

Dokumen lain yang digunakan adalah perundang-undangan yang mendukung terkait permasalahan pemidanaan dan permasalahan utang pajak, yaitu UndangUndang Nomor 19 Tahun 1997 tentang Penagihan Pajak dengan Surat Paksa yang diubah dengan Undang-Undang Nomor 19 Tahun 2000, Undang-Undang Nomor 14 Tahun 2002 tentang Pengadilan Pajak dan Kitab Undang-Undang Hukum Pidana (KUHP).

${ }^{4}$ Soerjono Soekanto dan Sri Mamudji, Penelitian Hukum Normatif, Suatu Tinjauan Singkat, Cetakan kedua, CV. Rajawali, Jakarta, 1986, hlm. 14. 


\section{Hasil Penelitian dan Pembahasan}

\section{Administrasi Pajak}

Dalam hidup bernegara, setiap orang diwajibkan untuk membayar pajak. Jadi, pajak sebagai kewajiban kenegaraan memberikan kontribusi untuk penerimaan negara berdasarkan Undang-undang Dasar $1945 .{ }^{5}$ Oleh karenanya pajak merupakan kewajiban semua warga masyarakat dan hukum pajak mengatur hubungan antara penguasa/negara dengan warganya (orang atau badan) dalam pemenuhan kewajiban perpajakan kepada negara. ${ }^{6}$ Dengan demikian hukum pajak tergolong dalam hukum publik yaitu hukum administrasi/tata usaha negara. Hukum pajak sebagai bagian hukum tata usaha negara bersumber pada peristiwa-peristiwa perdata, yang apabila dilanggar dapat diancam dengan pelanggaran pidana. ${ }^{7}$ Direktorat Jenderal Pajak sebagai lembaga hukum yang bertugas mengumpulkan uang pajak, melakukan tugasnya berlandaskan pada administrasi pemungutan pajak sesuai undang-undang pajak. Sekalipun hukum pajak bagian dari hukum administrasi, materi pajak memang tidak lepas dari hukum perdata maupun pidana. Hukum pajak memiliki keterikatan kuat dengan hukum perdata dan juga hukum pidana. Bahkan istilah-istilah (terminologi hukum) yang digunakan dalam hukum pajak banyak mengambil dari istilah yang digunakan dalam hukum perdata maupun pidana. ${ }^{8}$

Dekatnya hubungan hukum pajak dengan hukum perdata maupun pidana bisa dimaklumi karena segala macam transaksi ekonomi dalam hukum perdata menjadi sasaran atau objek dari hukum pajak. Soal kealpaan dan kesengajaan yang diatur dalam Pasal 38 dan Pasal 39 UU KUP pada dasarnya mengacu pada pengertian kealpaan dan kesengajaan dalam hukum pidana. Demikian juga misalnya soal Wajib Pajak yang memindahtangankan atau memindahkan hak atau merusak barang yang

\footnotetext{
${ }^{5}$ Pasal 23A Amandemen UUD 1945 menegaskan bahwa pajak dan pungutan lain yang bersifat memaksa untuk keperluan negara diatur dengan undang-undang.

${ }^{6}$ Anshari Ritonga, Pembaharuan Perpajakan dan Hukum Fiskal Formal Indonesia, Yayasan Bina Baca Aksara, Jakarta, 2007, hlm. 19.

${ }^{7}$ Ibid., hlm. 20. Lihat juga buku yang ditulis Wirawan B. Ilyas dan Richard Burton, Hukum Pajak, Edisi 5, Salemba Empat, Jakarta, 2010, hlm. 14-15.

${ }^{8}$ Misalnya soal daluwarsa utang pajak yang diatur dalam Pasal 22 UU KUP mengacu pada daluwarsa dalam hukum perdata. Demikian juga soal pengertian hak mendahulu yang diatur dalam Pasal 21 UU KUP secara jelas mengacu pada ketentuan yang diatur dalam Pasal 1139 KUH Perdata. Pasal 1139 KUHPerdata yang menyebutkan piutang-piutang yang diistimewakan. Pengertian diistimewakan sama dengan pengertian didahulukan.
} 
telah disita karena tidak melunasi utang pajaknya akan diancam dengan Pasal 231 Kitab Undang-Undang Hukum Pidana (KUHP).

Bahkan dalam Kitab Undang-Undang Hukum Perdata (KUHPerdata), khususnya buku ketiga tentang Perjanjian, bisa dikatakan semuanya merupakan transaksi ekonomi yang bersifat perdata yang mempunyai aspek hukum pajak. Berbagai macam perjanjian yang diatur dalam hukum perdata umumnya akan berdampak pada aspek pajak, kecuali perjanjian tertentu seperti hibah tidak berdampak pada aspek pengenaan pajaknya. ${ }^{9}$ Hubungan yang jelas tampak bahwa dalam hukum pajak selalu mencari dasar kemungkinan pemungutan pajak berdasarkan perbuatan hukum perdata. Perjanjian, kekayaan dan warisan adalah contoh perdata yang menjadi dasar kemungkinan pemungutan pajak berdasarkan undang-undang pajak. Jadi, segala kegiatan ekonomi akan dipantau dari sisi pengenaan pajak untuk kepentingan negara. Proses administrasi pengenaan pajak (pemajakan) inilah yang diatur dalam hukum pajak, termasuk proses penyelesaian hukumnya sebagai bagian dari hukum administrasi.

Proses pemajakan itu sendiri merupakan sebagian dari kegiatan administrasi perpajakan. Istilah administrasi perpajakan dapat diartikan secara sempit dan secara luas. Dalam pengertian sempit, administrasi perpajakan merupakan penatausahaan dan pelayanan atas hak-hak dan kewajiban-kewajiban pembayar pajak. Sedangkan dalam arti luas, administrasi perpajakan dipandang sebagai fungsi, sistem dan lembaga. ${ }^{10}$

Sebagai fungsi, administrasi perpajakan meliputi fungsi perencanaan, pengorganisasian, dan pengendalian perpajakan. Sebagai sistem, administrasi perpajakan merupakan seperangkat unsur yaitu peraturan perundang-undangan, sarana dan prasarana, aparat dan Wajib Pajak yang berkaitan yang secara bersamasama menjalankan tugas untuk mencapai tujuan tertentu. Sedangkan sebagai lembaga, administrasi perpajakan merupakan institusi yang mengelola sistem dan melaksanakan proses pemajakan.

\footnotetext{
${ }^{9}$ Lihat misalnya dalam Pasal 4 ayat (3) huruf a angka 2 Undang-Undang Nomor 7 Tahun 1983 yang telah diubah dengan Undang-Undang Nomor 36 Tahun 2008 tentang pajak Penghasilan. Lengkapnya disebutkan sebagai berikut: Yang dikecualikan dari objek pajak adalah harta hibahan yang diterima oleh keluarga sedarah dalam garis keturunan lurus satu derajat, badan keagamaan, badan pendidikan, badan sosial termasuk yayasan, koperasi atau orang pribadi yang menjalankan usaha mikro dan kecil, yang ketentuannya diatur dengan atau berdasarkan Peraturan Menteri Keuangan.

${ }^{10}$ Gunadi, “Reformasi Administrasi Perpajakan Dalam Rangka Kontribusi Menuju Good Governance,” Pidato Pengukuhan sebagai Guru Besar Ilmu Perpajakan Fakultas Ilmu Sosial dan Ilmu Politik, UI, Jakarta, 2004.
} 
Dari uraian ini terlihat bahwa pemungutan pajak (pemajakan) adalah serangkaian proses administrasi yang bertujuan untuk memperoleh uang pajak berlandaskan undang-undang perpajakan yang mengaturnya. Serangkaian proses administrasi inilah yang menjadi alat pemerintah mencapai tujuan penerimaan pajak termasuk didalamnya proses penegakan hukum melalui cara atau mekanisme hukum administrasi yang juga telah diatur dalam undang-undang pajak itu sendiri. ${ }^{11}$ Sayangnya, upaya hukum yang sudah diatur dengan jelas dalam undang-undang pajak acapkali tidak mendapat satu pemahaman yang sama dengan aparat penegak hukum lainnya.

Padahal, kalau saja terjadi sebaliknya, semua aparat hukum mengacu pada pemahaman sama sesuai undang-undang pajak, dipastikan dunia usaha termasuk aparatur pajak tidak menjadi resah. Keresahan dunia usaha dan petugas pajak akan praktek pemidaann pantas dicermati kalangan penegak hukum. ${ }^{12}$ Alangkah berbahaya bila saja sasaran penerimaan pajak menjadi terganggu akibat praktek pemidanaan yang tidak tepat dilakukan oleh pihak penegak hukum (kepolisian, kejaksaan dan hakim pengadilan umum). Kelanjutan progran pembangunan bersumberkan dana pajak akan tidak berjalan akibat pemidanaan dalam praktek hukum pajak.

Memorandum of Understanding (MoU) yang diadakan pihak Kepolisian dan Direktorat Jenderal Pajak, beberapa waktu lalu, tampaknya juga belum mencapai sasaran terkait penjelasan hukum administrasi dalam hukum pajak yang patut diketahui pihak kepolisian. ${ }^{13} \mathrm{MoU}$ yang ditandatangani kedua belah pihak seakan hanya sekedar upaya kerjasama semata tanpa dibarengi dengan penuntasan pemahaman yang sama diantara kedua instansi tersebut. Mochamad Tjiptardo, selaku Direktur Jenderal Pajak, kala itu mengatakan bahwa MoU adalah payung

\footnotetext{
${ }^{11}$ Proses penegakan hukum dalam hukum pajak sudah sangat jelas mempunyai jalur hukumnya sendiri dengan upaya hukum yang diatur dalam Pasal 25 dan Pasal 27 UU KUP mengenai upaya hukum Keberatan, serta adanya Undang-Undang Nomor 14 Tahun 2002 tentang Pengadilan Pajak yang memproses upaya hukum Banding dan upaya hukum Peninjauan Kembali.

${ }^{12}$ Richard Burton, Lumpuhnya Hukum Pajak, Artikel, Sinar Harapan, Selasa, 1 Maret 2011. Ulasan dalam artikel tersebut menunjukkan adanya keresahan bagi pegawai pajak dalam melaksanakan tugasnya karena bisa dikriminalisasi. Padahal petugas pajak melaksanakan tugas administrasi sesuai undang-undang perpajakan. Kejadian ini menimpa Maruli Manurung, pegawai pajak yang memproses upaya hukum keberatan yang diajukan oleh Wajib Pajak. Ternyata, Maruli dijatuhi vonis pidana oleh Majelis Hakim Pengadilan Negeri Jakarta Selatan karena dianggap merugikan keuangan negara. Sedangkan bagi Wajib Pajak, keresahan timbul karena penegak hukum menggunakan pasal pidana. Padahal pajak adalah bagian dari hukum administrasi. Misalnya saja soal pengisian Surat Pemberitahuan (SPT) yang mungkin saja ada data yang kurang atau tidak dilaporkan. Data yang kurang atau tidak dilaporkan semata-mata tidak bisa dilihat sebagai tindak pidana.

${ }^{13}$ Kompas.com tanggal 23 Pebruari 2010.
} 
hukum dalam upaya menagih utang pajak bagi penunggak pajak. Penulis menilai pernyataan tersebut kurang tepat. MoU bukanlah payung hukum yang bisa digunakan oleh aparatur pajak maupun pihak kepolisian. MoU hanyalah sekedar surat kesepahaman di antara dua instansi untuk melakukan langkah hukum sesuai Undang-undang yang berlaku. MoU tidak mempunyai kekuatan hukum yang mengikat bagi aparat pajak maupun aparat kepolisian, termasuk dalam menagih utang pajak. ${ }^{14}$ Hikmahanto menegaskan bahwa secara teoritis dokumen MoU tidak merupakan hukum yang mengikat para pihak. Agar mengikat secara hukum, harus ditindaklanjuti dengan sebuah perjanjian. Kesepakatan MoU lebih bersifat ikatan moral. MoU bisa dianalogikan sebagai lembaga "pertunangan", bukan lembaga "perkawainan". ${ }^{15}$

\section{Kajian Hukum}

Dalam persidangan di Pengadilan Negeri Jakarta Pusat, ternyata diketahui bahwa Majelis Hakim Pengadilan menolak eksepsi dari Manajer Asian Agri Group yang diwakili oleh Pengacaranya. Eksepsi yang disampaikan Pengacara Asian Agri Group pada dasarnya menegaskan bahwa penyelesaian kasus dugaan penyelewengan pajak merupakan kewenangan Pengadilan Pajak karena merupakan persoalan atau sengketa pajak yang sudah diatur dalam undang-undang pajak. ${ }^{16}$ Sengketa pajak yang muncul sebagai akibat dikeluarkannya keputusan yang tidak memuaskan Wajib Pajak harus diupayakan penyelesaiannya secara baik, sederhana, murah, dan cepat. Artinya, ada jalan penyelesaian secara kekeluargaan dengan musyawarah antara kedua belah pihak yang bersengketa dan tetap memperhatikan peraturan perpajakan. ${ }^{17}$

\footnotetext{
${ }^{14}$ Soal utang pajak sudah diatur dengan Undang-Undang Nomor 19 Tahun 1997 yang dibah dengan UndangUndang Nomor 2000 tentang Penagihan Pajak dengan Surat Paksa. MoU bukan dasar hukum untuk menagih utang pajak. MoU tidak mengikat secara hukum, tetapi ia hanya mengikat secara moral. MoU seharusnya ditindaklanjuti dengan berbagai kepentingan dalam memahami masing-masing undang-undang khususnya pemahaman akan UU pajak dan UU Pidana.

${ }^{15}$ Hikmahanto Juwana, Bunga Rampai Hukum Ekonomi dan Hukum Internasional, Cetakan I, Penerbit Lentera Hati, Jakarta, 2002, hlm. 123.

${ }^{16}$ Pasal 1 UU No. 14 Tahun 2002 tentang pengadilan Pajak menegaskan bahwa sengketa pajak adalah sengketa yang timbul dalam bidang perpajakan antara wajib pajak atau penanggung pajak dengan pejabat yang berwenang sebagai akibat dikeluarkannya keputusan yang dapat diajukan banding atau gugatan kepada Pengadilan Pajak berdasarkan peraturan perundang-undangan perpajakan, termasuk gugatan atas pelaksanaan penagihan berdasarkan Undang-undang Penagihan Pajak dengan Surat Paksa.

${ }^{17}$ Wiratni Ahmadi, Perlindungan Hukum Bagi Wajib Pajak Dalam Penyelesaian Sengketa Pajak, Cetakan Pertama, Refika Aditama, Bandung, 2006, hlm. 52-53.
} 
Namun, Majelis Hakim menolak eksepsi Pengacara Asian Agri Group dan berpendapat bahwa kasus Asian Agri Group bukan merupakan sengketa pajak karena tidak adanya surat ketetapan pajak yang diterbitkan oleh Direktorat Jenderal Pajak. Kalau sengketa pajak akan ada upaya hukum untuk menyelesaikannya, yaitu melalui upaya hukum keberatan. Oleh karenanya, kasus Asian Agri Group bisa diadili oleh Pengadilan Negeri. ${ }^{18}$

Penolakan eksepsi inilah yang perlu mendapat kajian apakah benar argumentasi hukum yang dibangun Majelis Hakim hingga kasus dugaan penggelapan pajak bisa dipidana karena tidak adanya surat ketetapan pajak yang diterbitkan Direktorat Jenderal Pajak sebagai dasar adanya sengketa pajak. Kalau permasalahan pajak dibawa dalam ranah hukum pidana, tentu menjadi kontradiktif terkait proses administrasi pajak yang tujuan utamanya mengumpulkan uang pajak. Pilihan memidanakan Wajib Pajak atau memprioritaskan penerimaan tentu menjadi politik kepentingan pemerintah. ${ }^{19}$ Untuk itu, kajian komprehensif pemidanaan atas pajak, patut menjadi perhatian serius agar tidak terjadi keresahan terus menerus di kalangan dunia usaha dan pegawai pajak.

Seperti diuraikan diatas, dalam banyak literatur disebutkan bahwa hukum pajak tergolong sebagai hukum publik, termasuk hukum administrasi/tata usaha negara. ${ }^{20}$ Jalur hukum administrasi (hukum pajak) mempunyai cara penyelesaiannya sendiri sesuai dengan aturan yang sudah ditegaskan dalam undang-undang pajak yang mengaturnya. Kalau begitu, menyelesaikan persoalan administrasi pajak dengan cara pidana menjadi kontradiktik ketika negara membutuhkan dana pajak sebagai sumber pembiayaan pembangunan yang tiap tahun jumlahnya terus naik (meningkat). ${ }^{21}$ Persoalan memidana Wajib Pajak jelas membawa keresahan tersendiri bagi pelaku dunia usaha. Artinya, pelaku usaha menjadi takut dipidana ketika persoalan penghitungan pajak yang cukup rumit akan dipersoalkan menjadi persoalan berindikasikan tindak pidana.

\footnotetext{
${ }^{18}$ Harian Ekonomi Neraca, Pengadilan tolak eksepsi terdakwa, 1 April 2011.

${ }^{19}$ Richard Burton, Kajian Aktual Perpajakan, Salemba Empat, Jakarta, 2009, hlm. 137.

${ }^{20}$ Anshari Ritonga, Pembaharuan Perpajakan Dan Hukum Fiskal Formal Indonesia, Pustaka El Manar, Jakarta, 2007, hlm. 19.

${ }^{21}$ Data Direktorat Jenderal Pajak menyebutkan target penerimaan pajak 2011 diperkirakan mencapai angka Rp. 764.480.000.000.000,00. Dibandingkan realisasi penerimaan pajak 2010 sebesar Rp. 649.040.000.000.000,00, berarti terjadi peningkatan sebesar Rp. 115.440.000.000.000,00. Kenaikan yang begitu besar menunjukkan bahwa pajak selalu menjadi sumber yang paling diandalkan untuk bisa melanjutkan berbagai program pembangunan yang sudah direncanakan oleh pemerintah.
} 
Pendapat ketiga pakar hukum dalam kasus Asian Agri Group di atas, menarik untuk dikaji dan dipahami dengan baik oleh semua aparat penegak hukum terutama aparat Kepolisian, Kejaksaan, maupun Hakim. Kesamaan visi memandang pajak tidak boleh dipidana karena merupakan bagian dari hukum administrasi, harus menjadi perhatian bersama. Hukum pajak sebagai bagian hukum tata usaha negara memang bersumber pada peristiwa perdata, yang apabila dilanggar dapat diancam dengan pelanggaran pidana. Dalam hukum pajak memuat unsur-unsur (i) hukum tata negara dan hukum tata usaha negara, (ii) hukum perdata, dan (iii) hukum pidana. ${ }^{22}$ Menyamakan persepsi demikian memang tidak mudah. Diperlukan satu koordinasi yang kuat. Presiden selaku pimpinan eksekutif sebaiknya memimpin proses koordinasi demikian.

Oleh karena berbicara soal pajak bukanlah milik Direktorat Jenderal Pajak Kementerian Keuangan semata, tetapi milik seluruh komponen bangsa. Seluruh pemangku kepentingan (stakeholders) pajak $^{23}$ harus melihat ke arah tujuan yang sama bahwa pajak dimaksudkan untuk membangun bangsa. Direktorat Jenderal Pajak hanyalah instansi yang bertugas mengadministrasikan jumlah pemungutan pajak serta mengawasi pelaksanaan undang-undang perpajakan. Direktorat Jendearl Pajak Kementerian keuangan harus didukung oleh seluruh instansi yang ada baik pemerintah maupun swasta.

Sebagai contoh, bisa kita lihat, bahwa ketika Wajib Pajak melakukan kesalahan mengisi Surat Pemberitahuan (SPT), Wajib Pajak berhak melakukan pembetulan atas SPT yang telah diisi namun terdapat kesalahan. Pasal 8 ayat (1) UU KUP secara tegas menyatakan bahwa “Wajib pajak dengan kemauan sendiri dapat membetulkan Surat pemberitahuan yang telah disampaikan dengan menyampaikan pernyataan tertulis dengan syarat Direktur Jenderal Pajak belum melakukan tindakan pemeriksaan". Penjelasan pasal ini menegaskan bahwa terhadap kekeliruan dalam pengisian Surat Pemberitahuan yang dibuat Wajib Pajak, Wajib Pajak masih berhak untuk melakukan pembetulan atas kemauan sendiri, dengan syarat Direktur Jenderal Pajak belum mulai melakukan tindakan pemeriksaan. Yang dimaksud dengan mulai melakukan tindakan pemeriksaan adalah pada saat Surat Pemberitahuan

\footnotetext{
${ }^{22}$ Anshari Ritonga, Op.Cit., hlm. 20.

23 Stakeholders pajak termasuk didalamnya para anggota Dewan Perwakilan Rakyat (DPR), Dewan Perwakilan daerah (DPD), Majelis Permusyawaratan Rakyat (MPR), semua lembaga tinggi negara, Para Usahawan, Buruh, Anakanak sekolah, Perawat, Petani, dan lain sebagainya. Oleh karena pemanfaatan akan pajak dapat dirasakan oleh seluruh lapisan masyarakat.
} 
Pemeriksaan Pajak disampaikan kepada Wajib Pajak, wakil, kuasa, pegawai, atau anggota keluarga yang telah dewasa dari Wajib Pajak.

Bahkan, sekalipun terhadap Wajib Pajak telah dilakukan pemeriksaan, tetapi belum dilakukan penyidikan, Wajib Pajak tetap diberikan kesempatan untuk mengungkapkan ketidakbenaran perbuatannya disertai pelunasan pembayaran pajak ditambah sanksi administrasi denda sebesar 150\% dari pajak yang kurang dibayar, sesuai ketentuan Pasal 8 ayat (3) UU KUP. Namun apabila telah dilakukan tindakan penyidikan dan mulainya penyidikan tersebut diberitahukan kepada Penuntut Umum, kesempatan untuk mengungkapkan ketidakbenaran perbuatannya sudah tertutup bagi Wajib Pajak. Menyikapi ketentuan di atas, sejatinya dapat dipahami bahwa persoalan pajak adalah persoalan administrasi pembayaran atas utang pajak yang harus dibayar Wajib Pajak. Undang-undang pajak selalu memberikan kesempatan kepada Wajib Pajak untuk melunasi utang pajak dengan cara membetulkan SPT-nya. Dengan kata lain, penyelesaian utang pajak tidak tepat apabila dilakukan dengan praktik pemidanaan kepada Wajib Pajak.

Argumen hukum secara nyata bisa dilihat dari roh yang diatur dalam ketentuan Pasal 44 B UUKUP yang juga menekankan pada aspek pembayaran uang sebagai pengganti sanksi pidana. Pasal tersebut dengan tegas menyatakan bahwa "untuk kepentingan penerimaan negara, atas permintaan Menteri Keuangan, Jaksa Agung dapat menghentikan penyidikan tindak pidana di bidang perpajakan paling lama dalam jangka waktu 6 bulan sejak tanggal surat permintaan." Makna kata-kata "untuk kepentingan penerimaan negara", tidak dijelaskan dalam undang-undang. Namun, dalam pandangan penulis maksud "untuk kepentingan penerimaan negara" tidak lain dimaksudkan selain ingin menitikberatkan atau menekankan bahwa pajak bukan bertujuan memidana seseorang tetapi lebih kepada kepentingan mengumpulkan uang pajak untuk kepentingan penerimaan negara. Penerimaan negara bisa diartikan sebagai sejumlah uang yang patut dikumpulkan untuk kepentingan penerimaan negara. Tujuan pajak adalah mengumpulkan uang bagi kepentingan negara guna membangun berbagai macam fasilitas publik.

Bukti digunakan atau diterapkannya ketentuan Pasal 44 B UU KUP terlihat dalam kasus Paulus Tumewu yang sudah P-21 (sudah selesai disidik oleh pihak Kejaksaan Agung) dan tinggal dilanjutkan ke tingkat Penuntutan, lalu dihentikan dan dinyatakan selesai. Awalnya, Paulus Tumewu dikenakan Surat Ketetapan Pajak (SKP) kekurangan pembayaran PPh 2004 sebesar Rp. 7.900.000.000.000,00. Atas 
kekurangan utang pajak tersebut dilunasi tanggal 28 Nopember 2005. ${ }^{24}$ Atas dasar ketentuan Pasal 44 B UU KUP itulah, Jaksa Agung menghentikan penyidikannya. Di sini berarti ada kepentingan penerimaan negara yang jauh lebih penting dibandingkan proses pemidanaan sesuai hukum pidana.

Dalam UU KUP memang diatur bahwa dalam hal Wajib Pajak tidak benar dalam melaksanakan kewajiban pembayaran pajak, selayaknya dilakukan pemeriksaan. Ujung dari tindakan pemeriksaan diterbitkan surat ketetapan pajak. Hal ini diatur dengan tegas dalam Pasal 15 UUKUP, yang menyatakan “Direktur Jenderal Pajak dapat menerbitkan Surat Ketetapan pajak Kurang Bayar Tambahan dalam jangka waktu 5 tahun setelah saat terutangnya pajak atau berakhirnya Masa Pajak, Bagian Tahun Pajak, atau Tahun Pajak apabila ditemukan data baru yang mengakibatkan penambahan jumlah pajak yang terutang setelah dilakukan tindakan pemeriksaan dalam rangka penerbitan Surat Ketetapan pajak Kurang Bayar Tambahan".

Ketentuan Pasal 15 UU KUP inilah yang diungkapkan oleh Sunarto, Saksi Ahli Pajak, dalam persidangan di Pengadilan Negeri. Artinya, setiap Wajib Pajak dapat diterbitkan Surat Ketetapan Pajak Kurang Bayar Tambahan (SKPKBT) jika diketahui masih ada utang pajak yang belum dibayar oleh Wajib Pajak melalui proses pemeriksaan sesuai ketentuan yang berlaku. Pasal 15 UU KUP ini menjadi alat yang sangat ampuh bagi Direktorat Jenderal Pajak untuk terus melakukan tindakan menagih utang pajak apabila diketahui Wajib pajak belum menjalankan kewajiban perpajakannya dengan baik.

Dari semua pasal yang disebutkan di atas, pada prinsipnya dapat disimpulkan bahwa undang-undang pajak lebih memberikan solusi penyelesaian pajak dengan menekankan pada aspek administratif melalui pembayaran pajak dengan sarana surat ketetapan pajak, bukan pada memidana Wajib Pajak. Proses pemeriksaan pajak bukanlah dimaksudkan untuk memidana Wajib Pajak tetapi lebih mengutamakan pada proses administrasi dengan menerbitkan surat ketetapan pajak sebagai dasar untuk menagih utang pajak. Kalau begitu, pertanyaannya adalah mengapa ada unsur pidana dalam hukum pajak? Dalam kajian penulis, pasal pidana yang diatur dalam undang-undang pajak tidak atau kurang tepat. ${ }^{25}$ Pasal pidana boleh saja dimasukan

\footnotetext{
${ }^{24}$ Harian Bisnis Indonesia, tanggal 21 April 2010.

${ }^{25}$ Contoh tidak tepat dan hampir tidak pernah digunakan dalam praktek adalah Pasal 39 ayat (1) huruf a UU KUP yaitu bagi orang yang dengan sengaja tidak mendaftarkan diri untuk memperoleh Nomor Pokok Wajib pajak (NPWP). Pasal ini seakan menjadi pasal pidana yang mati karena memang agak ganjil kalau digunakan. Ancaman pidana paling singkat 6 bulan dan paling lama 6 tahun tidak pernah terjadi.
} 
dalam undang-undang pajak, tetapi perannya menjadi kurang atau tidak penting. Bahkan ekstrimnya, pasal pidana tidak perlu lagi ada dalam undang-undang pajak kalau memang hukum pajak dipandang sebagai hukum administrasi yang murni.

Kekeliruan memasukkan pasal pidana dalam hukum pajak, dalam pandangan penulis tampaknya didasarkan pada dua alasan. Pertama, pajak adalah sarana bagi negara untuk membiayai pembangunan guna kesejahteraan masyarakat. ${ }^{26}$ Tugas negara memberikan kemakmuran dan keadilan dari berbagai sisi kehidupan yang dibutuhkan masyarakat, khsususnya dalam hal membangun berbagai fasilitas publik. Kalau sumber penerimaan pajak tidak tercapai, maka berbagai program pembangunan tidak akan berjalan lancar. ${ }^{27} \mathrm{Kedua}$, pajak adalah satu-satunya instrumen paling adil memberikan tingkat kesejahteraan bagi masyarakat. Hanya dengan instrumen pajaklah setiap bangsa akan bisa menciptakan kesejahteraan dan keadilan yang diharapkan masyarakatnya. Sayangnya, para penegak hukum kurang memahami persoalan hukum pajak.

Kalau saja pemahaman hukum pajak bisa dipahami sambil memahami latar belakang sejarah peradaban pajak sejak dahulu, sejatinya ranah pidana tidak perlu dilakukan. ${ }^{28}$ Sejak jaman nabi, sampai masa kolonial (penjajahan), dan sampai sekarang ini, selalu saja aspek pembayaran menjadi fokus utama. Jaman penjajahan, misalnya, rakyat dipaksa membayar pajak dengan uang. Kalau pajak tidak dibayar, penjajah akan mengambil berbagai macam barang atau binatang yang dimiliki rakyat. Dengan kata lain, barang ataupun binatang adalah satu pengganti dari uang yang tidak dibayarkan oleh rakyat.

\section{Sanksi Administrasi}

Pola berfikir memasukkan unsur pidana dalam hukum pajak, menjadi bias ketika pajak selalu menekankan pada pemberian sanksi administrasi dalam banyak pasal

${ }^{26}$ Dalam Anggaran Pendapatan dan belanja Negara (APBN) yang disahkan oleh DPR setiap tahun, tegas disebutkan bahwa penerimaan pajak mendominasi (menjadi primadona) seluruh penerimaan APBN. Lebih dari 70\% sumber pembiayaan negara berasal dari pajak. APBN Tahun 2010, misalnya mengalokasikan penerimaan pajak sebesar Rp. 600.000.000.000.000,00 lebih. Dan di 2011, penerimaan pajak direncanakan 708.000.000.000.000,00 lebih.

${ }^{27}$ Pembangunan fasilitas sosial seperti sekolah, puskesmas, dana bantuan Operasional Sekolah (BOS) serta jalan, menjadi satu keharusan yang tidak bisa ditunda.

${ }^{28}$ Dalam kitab suci ajaran berbagai agama yang ada (Islam, Kristen, Hindu dan Budha, terdapat ayat yang mewajibkan untuk membayar pajak. Ini menunjukkan bahwa sejarah peradaban bangsa sejak jaman nabi-nabi, sudah ada dan wajib dibayar oleh rakyat kepada Pemerintah. Nabi Isa atau Yesus, sudah memberikan contoh untuk membayar pajak. Kalimat yang diucapkannya adalah "Berikanlah kepada Kaisar apa yang wajib kamu berikan kepada Kaisar dan kepada Allah apa yang wajib kamu berikan kepada Allah" Penjelasan soal ini dapat dilihat pula dalam buku "Pajak Menurut Teologi Kristen” yang diterbitkan oleh Lembaga Penerbit Fakultas Ekonomi Universitas Indonesia, Tahun 2006. 
yang mengaturnya. Kalau ada pandangan mengecilkan sanksi administrasi dengan menggantinya dengan cara sanksi pidana, tentu kurang tepat. Menurut penulis, sanksi administrasi-pun bahkan bisa lebih memberikan efek jera dibandingkan efek jera dalam sanksi pidana sepanjang ukuran besaran sanksinya diperberat. Oleh karena sanksi administrasi bisa membuat seseorang menjadi bangkrut dengan menyita kekayaan seseorang untuk melunasi utang pajaknya. ${ }^{29}$ Sanksi administrasi seringkali dipandang ringan karena masih memberikan kebebasan secara fisik kepada seseorang. Kalau ukuran kebebasan secara fisik dalam sanksi pidana menjadi ukuran menilai berat ringannya sanksi, tentu tidak tepat. Oleh karenanya, perlu dikaji lagi agar penerapan sanksi pidana tidak menjadi kontra produktif dalam penerapan sanksi di dalam hukum pajak.

Memang, sanksi administrasi yang diatur dalam undang-undang perpajakan saat ini tergolong masih sangat ringan. Kalau saja sanksi administrasi dibuat lebih berat, diyakini pastinya akan memberikan efek jera lebih baik. Sanksi tidak menyampaikan SPT PPh Badan dengan hanya sebesar Rp. 1.000.000,00, ${ }^{30}$ tampaknya perlu lebih diperberat. Demikian pula untuk sanksi keterlambatan penyampaian SPT PPh Orang Pribadi hanya dikenakan sebesar Rp. 100.000,00. Sanksi ini perlu diubah dan diperberat lagi misalnya menjadi Rp. 10.000.000,00 agar setiap orang peduli terhadap pemenuhan kewajiban perpajakannya. Bahkan sanksi administrasi bunga sebesar 2\% per bulan karena adanya pembetulan SPT kurang bayar, patut diubah misalnya menjadi $10 \%$ atau $20 \%$, agar lebih memberikan efek jera pentingnya pajak dibayar kepada negara. ${ }^{31}$

Besaran pentingnya sanksi administrasi sebagai pengganti sanksi pidana, juga terlihat dalam ketentuan Pasal 44 B ayat (2) sebagai pengganti dari dilakukannya penghentian penyidikan. Pengganti sanksi dihentikannya penyidikan hanya 4 kali

\footnotetext{
${ }^{29}$ Pasal 12 UU No. 19 Tahun 1997 yang dirubah dengan UU No. 19 Tahun 2000 menegaskan bahwa apabila utang pajak tidak dilunasi Penanggung Pajak dalam jangka waktu sebagaimana dimaksud dalam Pasal 11 (dua kali dua puluh empat jam), pejabat menerbitkan Surat Perintah Melaksanakan Penyitaan. Bahkan dalam Pasal 33-nya ditegaskan bahwa terhadap Wajb Pajak bisa dilakukan tindakan penyanderaan yang wujudnya berupa pengekangan sementara waktu terhadap kebebasan Penanggung Pajak dengan menempatkannya pada tempat tertentu.

${ }^{30}$ Pasal 7 UU KUP menyatakan bahwa Apabila Surat Pemberitahuan tidak disampaikan dalam jangka waktu sebagaimana dimaksud dalam Pasal 3 ayat (3) atau batas waktu perpanjangan penyampaian Surat Pemberitahuan sebagaimana dimaksud dalam Pasal 3 ayat (4), dikenai sanksi administrasi berupa denda sebesar Rp. 500.000,00 untuk Surat Pemberitahuan Masa Pajak Pertambahan Nilai, Rp. 100.000,00 untuk Surat Pemberitahuan Masa lainnya, dan sebesar Rp. 1.000.000,00 untuk Surat Pemberitahuan Tahunan Pajak Penghasilan Wajib pajak Badan serta sebesar Rp. 100.000,00 untuk Surat Pemberitahuan Tahunan Pajak Penghasilan Wajib Pajak orang pribadi.

${ }^{31}$ Sejak UU KUP Tahun 1983 sampai dengan UU No. 28 Tahun 2007 (sudah lebih dari 25 tahun), besaran sanksi administrasi baik denda, bunga maupun kenaikan tidak terlalu besar. Hal ini mengakibatkan kurangnya wibawa hukum pajak dalam aplikasinya sehari-hari.
} 
dari jumlah pajak yang tidak atau kurang dibayar. Barangkali penyusun undangundang pajak saat itu memandang besaran sanksi tersebut dipandang cukup besar. ${ }^{32}$ Kalau kita perhatikan, ternyata yang ditegaskan dalam konteks pengganti penyidikan dalam Pasal 44 B ayat (2) UU KUP adalah persoalan administrasi. Penegasan yang diatur dalam pasal tersebut seakan-akan ingin mengembalikan pada 'roh' hukum pajak yang sebenarnya bahwa persoalan pajak adalah persoalan administrasi. Jadi, titik berat pengenaan sanksi pajak bukanlah pada aspek pidana tetapi lebih pada aspek hukum administrasi sebagaimana diuraikan di atas.

Dalam literatur hukum adminsitrasi negara diketahui bahwa objeknya ada dua macam, yaitu objek material dan objek formal. ${ }^{33}$ Objek material dimaksud adalah manusia yaitu aparat pemerintah atau aparat administrasi negara sebagai pihak yang memerintah dan warga masyarakat atau badan hukum privat sebagai pihak yang diperintah. Sedangkan Objek formal dimaksud adalah perilaku atau kegiatan atau keputusan hukum badan pemerintah baik yang bersifat peraturan (regeling) maupun yang bersifat ketetapan (beschiking). Banyaknya sanksi-sanksi administrasi yang diatur termasuk pengganti sanksi pidana dengan sanksi administrasi, memberikan kesimpulan bahwa praktek pemidanaan pajak terhadap Wajib Pajak menjadi kontradiktif dan tidak memberikan kemanfaatan sebagai satu tujuan hukum yang diharapkan. Seperti dikatakan Gustav Radbruch, bahwa pada hakekatnya hukum mengandung ide atau konsep-konsep yang dapat digolongkan sebagai suatu yang abstrak. Ke dalam kelompok yang abstrak termasuk ide tentang keadilan, kepastian hukum dan kemanfaatan sosial. ${ }^{34}$ Filosofi hukum pajak sejak awalnya tidak ditujukan untuk memidana Wajib Pajak tetapi untuk memperoleh uang pajak bagi kemanfaatan uang pajak itu sendiri untuk kepentingan masyarakat. Tujuan demikian tentu sejalan dengan tujuan kemanfaatan sebagaimana dimaksud oleh Radbruch.

Sudut pandang penegakan hukum pajak dengan cara pemidanaan harus segera diubah. Kecenderungan menggunakan sanksi pidana dalam hukum pajak dirasa sudah harus ditinggalkan untuk kepentingan hukum pajak sekaligus penerimaan pajak itu sendiri. Pendekatan penegakan hukum dengan menggunakan sanksi administrasi pada hukum pajak lebih memberikan manfaat besar dalam melakukan

\footnotetext{
${ }^{32}$ Penjelasan Pasal 44 B ayat (2) UU KUP hanya menyebutkan cukup jelas. UU tidak memberikan penjelasan lebih lanjut mengapa besaran sanksi administrasi hanya empat kali.

${ }^{33}$ Nomensen Sinamo, Hukum administrasi Negara, Suatu Kajian Kritis Tentang Birokrasi Negara, Cetakan Pertama, Jala Permata Aksara, Jakarta, 2010, hlm. 25.

${ }^{34}$ Satjipto Rahardjo, Penegakan Hukum, Suatu Tinjauan Sosiologis, Genta Publishing, Yogyakarta, 2009, hlm. 12.
} 
pembangunan di berbagai bidang kehidupan yang dananya bersumber dari pajak. Bahkan dengan adanya berbagai pembangunan di berbagai sektor kehidupan, pada akhirnya akan memberikan manfaat lain dalam menciptakan perubahan di masyarakat. Perubahan dalam arti memberikan kesejahteraan bagi masyarakat akan sangat dirasakan dalam penegakan hukum pajak yang dilaksanakan. Satjipto Rahardjo, mengutip Seidman, menekankan apabila pada suatu saat negara berkehendak untuk merubah masyarakat Indonesia menjadi masyarakat yang modern industrial, maka pada waktu itu pula masuk suatu nilai baru yaitu pembangunan. ${ }^{35}$

Oleh karenanya, kesaksian tiga orang ahli hukum dalam sidang dugaan penggelapan pajak kasus Asian Agri Group, sangat tepat guna kebaikan penerapan atau penegakan hukum pajak dimasa mendatang. Kesaksian ketiga ahli dalam sidang Asian Agri Group telah memberikan sumbangsih cukup besar dalam memetakan kembali pentingnya penegakan hukum pajak dari sisi hukum administrasi. Kecondongan menegakkan hukum pajak dengan menerapkan pada sisi hukum administrasi, bisa dikategorikan pula sebagai cara menegakan hukum secara progresif atau penerobosan hukum (pilihan hukum secara ekstrim) walaupun tidak tepat jika dilihat pada hukum positif adanya ketentuan pidana yang diatur dalam undangundang pajak.

\section{Penutup}

Ketika negara membutuhkan banyak dana untuk membangun berbagai fasilitas publik seperti jalan, jembatan, sekolah, rumah sakit, dan lainnya, maka tidak ada cara lain selain dengan cara pajak untuk memenuhi kebutuhan pembangunan tersebut. Masih banyaknya infrastruktur jalan yang rusak di berbagai wilayah Indonesia, terutama di daerah-daerah yang masih terbelakang dalam pembangunan infrastrukturnya serta berbagai fasilitas sosial yang belum ada seperti rumah sakit, sekolah, dan lain-lain, tentu memerlukan banyak dana untuk menyiapkannya. Pajak adalah jalan keluar yang bisa digunakan untuk memenuhi kebutuhan akan dana tersebut. Pajakjuga merupakan sumber penerimaan dalam negeri yang paling aman dan handal karena penerimaan dalam negeri lainnya seperti minyak/gas sangat tergantung pada pasaran minyak dunia. ${ }^{36}$

\footnotetext{
${ }^{35}$ Ibid., hlm. 130.

${ }^{36}$ Anshari Ritonga, Kebijakan Fiskal, Diakhir Orde Baru, Awal Era Reformasi, Dan Penghujung Dominasi IMF, Pustaka El Manar, Jakarta, 2006, hlm. 25.
} 
Kebutuhan akan dana yang demikian besar, mau tidak mau memerlukan sudut pandang yang jelas akan penerapan hukum pajak di masa mendatang sebagai landasan hukum pemungutan pajak. Hukum pajak sebagai bagian dari hukum administrasi haruslah dipandang sebagai hukum administrasi yang tidak boleh dibelokan ke arah pemidanaan. Kemauan para penegak hukum untuk memahami keadaan demikian perlu dikoordinasikan dengan baik. Aparatur penegak hukum patut memahaminya dengan benar agar tidak terjadi pemidanaan kepada Wajib Pajak. Kalau begitu, aspek pidana dalam undang-undang pajak perlu dikaji ulang agar tidak menjadi kontradiktif di dalam penerapannya seharai-hari. Jadi, penerapan sanksi administrasilah yang perlu didahulukan dibandingkan sanksi pidana dalam hukum pajak agar tujuan mensejahterakan dan memberikan keadilan bagi seluruh rakyat Indonesia bisa segera direalisasikan. Tujuan mensejahterakan dan memberikan keadilan bagi rakyat adalah tujuan yang sangat mendasar sebagaimana tercantum di dalam pembukaan UUD 1945.

Kesejahteraan dan keadilan bisa diwujudkan jika pemerintah mempunyai cukup dana untuk itu. Oleh karena itu, kita semua perlu memberikan dukungan agar kesejahteraan dan keadilan yang dicita-citakan bisa terwujud. Pundi APBN sebagai kantong tempat terkumpulnya pajak juga perlu diawasi dalam penggunaannya agar tidak salah sasaran. Keterlibatan seluruh stakeholder juga amat diperlukan dalam pengawasan uang pajak. Harapan terciptanya kesejahteraan dan keadilan melalui pemungutan pajak serta penegakan hukum pajak, kiranya bisa dipercepat melalui visi yang sama oleh semua penegak hukum terkait dengan pelaksanaan undang-undang pajak.

\section{Daftar Pustaka}

Ahmadi, Wiratni, Perlindungan Hukum Bagi Wajib Pajak Dalam Penyelesaian Sengketa Pajak, Refika Aditama, Bandung, 2006.

Burton, Richard, Kajian Aktual Perpajakan, Salemba Empat, Jakarta, 2009.

Gunadi, “Reformasi Administrasi Perpajakan Dalam Rangka Kontribusi Menuju Good Governance", Pidato Pengukuhan sebagai Guru Besar Ilmu Perpajakan Fakultas Ilmu Sosial dan Ilmu Politik Universitas Indonesia, Jakarta, 2004.

Ilyas, Wirawan dan Richard Burton, Hukum Pajak, Penerbit Salemba Empat, Edisi 4, Jakarta, 2008.

Juwana, Hukmahanto, Bunga Rampai Hukum Ekonomi Dan Hukum Internasional, Lentera Hati, Jakarta, 2002. 
Nomensen, Sinamo, Hukum Administrasi Negara, Penerbit Jala Permata Aksara, Cetakan Pertama, Jakarta, 2010.

Rahardjo, Satjipto, Penegakan Hukum, Suatu Tinjauan Sosiologis, Genta Publishing, Yogjakarta, 2009

Ritonga, Anshari, Kebijakan Fiskal Diakhir Orde Baru, Awal Era Reformasi, Dan Penghujung Dominasi IMF, Pustaka El Manar, Jakarta, 2006.

, Pembaharuan Perpajakan Dan hukum Fiskal Formal Indonesia, Pustaka El Manar, Jakarta, 2007.

Soekanto, Soerjono, Penelitian Hukum Normatif, Suatu Tinjauan Singkat, Cetakan Kedua, Penerbit CV. Rajawali, Jakarta, 1986.

Anggaran Pendapatan dan Belanja Negara (APBN) Tahun 2010.

Rencana Anggaran Pendapatan dan Belanja Negara (RAPBN) Tahun 2011.

Harian Bisnis Indonesia, Kasus Pajak Paulus Tumewu Diungkit, 21 April 2010.

Harian Ekonomi Neraca, Pengadilan Tolak Eksepsi Terdakwa, Jumat 1 April 2011.

Harian Seputar Indonesia, Sengketa Pajak Bukan Ranah Pengadilan Umum, Rabu 23 Maret 2011.

Harian Suara Pembaruan, Negara Rugi Pidanakan Kasus Pajak, Rabu 23 Maret 2011

Harian Suara Karya, Penanganan Kasus Pajak Ancam Iklim Usaha, Jumat 25 Maret 2011.

Kompas.com, "Polri Tempatkan Enam Penyidik di Ditjen Pajak", 23 Pebruari 2010.

Undang-Undang No. 6 Tahun 1983 sebagaimana diubah terakhir dengan UndangUndang No. 28 Tahun 2007 tentang Ketentuan Umum dan tata Cara Perpajakan.

Undang-Undang No. 19 Tahun 1997 sebagaimana diubah terakhir dengan UndangUndang No. 19 Tahun 2000 tentang Penagihan Pajak dengan Surat Paksa.

Undang-Undang No. 14 Tahun 2002 tentang Pengadilan Pajak. 